\title{
Novel Forms of Rewriting Aristophanes' Comedies: Comic Book Adaptations and Their Translations
}

\section{Asimakoulas, Dimitris. Rewriting Humour in Comic Books: Cultural Transfer and Translation of Aristophanic Adaptations. Palgrave Macmillan, 2019, pp. 189.}

Recent years have witnessed the trend that comedy studies combine with what were once considered separate disciplines, such as translation studies. Nevertheless, few studies have been conducted to investigate the linkages in the areas of comics studies and comedy studies. Rewriting Humour in Comic Books: Cultural Transfer and Translation of Aristophanic Adaptations, which is part of the series of Palgrave Studies in Translating and Interpreting, timely fills the gap by excavating humor in comic book adaptations of Aristophanes's comedies.

The book is composed of six chapters, including an introduction (chapter 1), a main body of 4 chapters, and a conclusion (chapter 6), together constituting a theoretically rich and empirically rigorous study.

The first chapter starts by stressing that Marvel Comics may use humor for branding purpose, considering that humor is something memorable that readers are instinctively willing to appreciate and share. The author then explains why he chooses the book adaptations of Aristophanes's comedies as the prime example of such branding, because the ancient dramaturg's recognizable name, image, and oeuvre play an indispensable role in the comic books' popularity. More recently, they have been translated from Greek into four languages, which represent a cultural flow. 
Chapter 2 discusses the trajectories of rewriting Aristophanic comedies by translators, teachers, philologists, theatre directors, and comic art creators in the light of Lefevere's concept of rewriting. The "rewriting chain" of Aristophanic comedies is firstly mapped out chronologically, addressing the variety of poetological and ideological agendas of rewriters (22). Among these rewritings, comic book adaptations and their translations, a novel form of reworking material into a multimodal text, are emphasized in this chapter. In addition, the author further reviews four waves of Aristophanic rewritings for young readers and accounts for the authors, the intentions, and the processes of Aristophanic comic book rewritings by archival work and interviews with creators, surviving translators, and publishers.

Chapter 3 shows how the comic books build on their play-text precedents and focuses specifically on the form, content, and structure of five Greek comedies and their respective Greek comic book adaptations, according to the chronological order of Aristophanes's writing: Acharnians, Peace, Women at the Thesmophoria, Frogs and Assembly of Women. To begin with, the author outlines a typical classical comedy that includes prologue/prologos, parodos, contest/agon, parabasis, episodeia, and exodos. Swerving away from this basic matrix, however, comic book rewritings feature several interdependent strategies, namely, integration, concretization in image, reculturalization, addition, condensation, and omission. Furthermore, the author exemplifies the application of these strategies in Aristophanic comic book rewritings. Then, the author offers a close reading of five comedies and their corresponding comic book adaptations, showing that the further manipulations of the source texts serve their humorous, political, and educational functions. Chapter 4 further extends the Aristophanic rewriting chain by setting five Greek comic book adaptations against their English translations. In the first place, this chapter emphasizes two models of humor in literature, Robson's two-tier model and Vandaele's poetics-informed model. Vandaele puts forward a more nuanced, poetics-informed model of humor in literature, in which "various types of humor come into focus: metanarrative humor, comic suspense, comic surprise and comic characterization" (82). In the case of comic books, the translated text is subject to a myriad of semantic, syntactic, and pragmatic changes in a multimodal narrative environment. Robson proposes a relatively wide-ranging approach to examine the translation of puns in Aristophanic comic book adaptations, based on Attardo's General Theory of Verbal Humor (GTVH) 
deriving from earlier incongruity models for the study of jokes. At the same time, translation may affect the presentation of comic tone causally linked to graphic style and give rise to comic suspense/surprise and comic characterization, insomuch that the effects of graphic style, as well as suspenseful surprises and characters, is expounded through examples from the translations of Aristophanic series by three translators, namely Bella Spiropoulo, Kyriakos Haritos, and Tassos Pougouras. Among five comedies, Peace, Acharnians, and Frogs are highlighted because the first two have overt political and anti-war themes, whilst Frogs has a more intertextual, literary orientation.

Chapter 5 elaborates on comic characterization by examining how the prototypical comic heroes' traits (resourcefulness, excess, and individualism) are transferred in the English translation of comic book adaptations, on the basis of traditional narratological approach to characterization presented in chapter 4. Comic books feature flat or round characters on textual and conceptual levels. Characters in Aristophanic comedies can be seen as one-dimensional, flat characters. Nonetheless, nuances of roundness and complexity can be conceptualized and detected if the concept of "comic heroism" is used as a tool of close reading of comics and their translations. "A comic hero is given a certain perspective of the world by the author, usually moral indignation against behaviours, ideologies, people or institutions and a self-assured, boastful attitude towards their own self-righteousness" (Rosen 232). As suggested by the author, graphical and linguistic choices of characters contribute to prototypical aspects of comic heroes in these humorous Aristophanic adaptations: resourcefulness, excess, and individualism. The following sections examine eight most significant characters appealing in key narrative moments in the multimodal make-up of comics to support the author's argumentation, thus rendering the characters in Aristophanic comic book adaptations "relatively round." English translated texts, meanwhile, are evaluated with the help of characterization features pertaining to "comic heroism."

The last chapter summarizes the main findings of the book and suggests directions for further research. For one thing, the author reviews the rewriting chain from the early nineteenth century to present, from exploratory translations and staging to adaptions for children. For another, the author pays close attention to humor dissemination in the novel types of rewriting, which in return echoes the questions posed in the introduction of the book. 
Readers may be impressed by the unique model for the analysis of comic book adaptations of Aristophanes's comedies, which is of great value to scholars interested in comedy, comics, and translation studies. The main merits of this book can be listed as follows. First and foremost, it is worthwhile to employ a rich array of interviews with creators, surviving translators, and publishers. The first-hand information ensures that the findings are relatively objective and accurate. Secondly, the structure is clear and logical, considering that each chapter has its own abstract, conclusion, and a reference list that helps readers understand the whole book. Thirdly, the plentiful figures and tables are unambiguous, which further deepen readers' comprehension and enhance the book's readability. Last but not least, the six chapters form a cohesive unity; chapter 3 offers a close reading of five original plays and their comic book adaptations, whilst chapters 4 and 5 further elaborate on Greek comic book adaptations and their English translations.

However, besides the strong points shown in this review, some points need more consideration. Firstly, only five Greek comedies and their respective comic book adaptations are analyzed. Though some generalized findings have been drawn from the analysis of these adaptations, it cannot be denied that more significant findings might be made if more comic book adaptations are involved. Furthermore, as indicated by the author, these adaptations of Aristophanes's comedies have recently been translated into four languages, but the author has only compared the Greek originals and the English versions. These findings might not be applicable when different languages are involved because the features of different languages and the interrelations between the source and the target languages might influence the adoption of different translation strategies and, consequently, affect the analysis model.

By and large, despite these potential demerits, the thought-provoking findings in this book have not only challenged the traditional comedy studies, but also shifted the attention of researchers to undertake further research to investigate the linkages in the areas of comics studies and comedy studies. In a word, the author has made a praiseworthy endeavor to make this book a success.

\section{Works Cited}

Rosen, Ralph Mark. “The Greek 'Comic Hero.” The Cambridge Companion to Greek Comedy, edited by Martin Revermann, Cambridge University Press, 2014. 


\section{(c) (i) (9)}

Creative Commons Attribution-NonCommercial-NoDerivatives 4.0 International License 